\title{
Hasil diagnostik Mycobacterium tuberculosis pada penderita batuk $\geq 2$ minggu dengan pewarnaan Ziehl-Neelsen di Puskesmas Bailang dan Puskesmas Bengkol Manado
}

\author{
${ }^{1}$ Stephanie O. Willar \\ ${ }^{2}$ John Porotu'o \\ ${ }^{2}$ Olivia Waworuntu
}

\author{
${ }^{1}$ Kandidat Skripsi Fakultas Kedokteran Universitas Sam Ratulangi Manado \\ ${ }^{2}$ Bagian Mikrobiologi Fakultas Kedokteran Universitas Sam Ratulangi Manado \\ Email: fanywilar@gmail.com
}

\begin{abstract}
Tuberculosis (TB) is an infectious disease caused by Mycobacterium tuberculosis. Transmission occurs by air droplet infection. Source of infection is sputum of pulmonary tuberculosis patients. To date, tuberculosis is still a global health problem. In Indonesia the number of tuberculosis cases increases annualy. Most tuberculosis patients complain of cough $\geq 2$ weeks. This study was aimed to determine the diagnostic results of $M$. tuberculosis in the sputum of patients cough $\geq 2$ weeks with Ziehl-Neelsen staining at Puskesmas Bailang and Bengkol. This was a descriptive study. Subjects were patients with complaints of cough $\geq 2$ weeks at Puskesmas Bailang and Bengkol. The results showed that there were 25 patients with cough $\geq 2$ weeks that came for treatment consisted of 12 patients at Puskesmas Bailang and 13 patients at Puskesmas Bengkol. Most of them were males and aged 36-55 years. There was 1 patient $(8.33 \%)$ that had positive result of acid-fast bacillus at Puskesmas Bailang however, at Puskesmas Bengkol none had positive result.
\end{abstract}

Keywords: tuberculosis, cough more than two weeks, BTA examination.

\begin{abstract}
Abstrak: Tuberkulosis (TB) adalah penyakit infeksi yang disebabkan oleh Mycobacterium tuberculosis. Penularan terjadi melalui udara dari droplet infeksi. Sumber infeksi ialah penderita tuberkulosis paru yang membatukkan dahaknya. Hingga saat ini tuberkulosis masih merupakan masalah kesehatan dunia. Di Indonesia kasus tuberkulosis menunjukkan peningkatan dari tahun ke tahun. Diantara sekian banyak kasus tuberkulosis, pasien datang berobat dengan keluhan batuk $\geq 2$ minggu. Penelitian ini bertujuan untuk mengetahui hasil diagnostik M. tuberculosis dari sputum penderita batuk $\geq 2$ minggu dengan pewarnaan ZiehlNeelsen di Puskesmas Bailang dan Bengkol. Jenis penelitian ialah deskriptif. Subjek penelitian ialah pasien dengan keluhan batuk $\geq 2$ minggu di Puskesmas Bailang dan Bengkol. Hasil penelitian mendapatkan sebanyak 25 pasien dengan batuk $\geq 2$ minggu yang datang berobat di Puskesmas Bailang dan Bengkol, terdiri dari 12 pasien dari Bailang dan 13 pasien dari Bengkol. Keluhan batuk $\geq 2$ minggu lebih banyak ditemukan pada laki-laki, dan usia 3655 tahun. Hasil pemeriksaan BTA di Puskesmas Bailang ditemukan 1 pasien $(8,33 \%)$ positif sedangkan di Puskesmas Bengkol tidak ditemukan BTA positif.
\end{abstract}

Kata kunci: tuberkulosis, batuk lebih dari dua minggu, pemeriksaan BTA.

Tuberkulosis (TB) adalah penyakit infeksi yang disebabkan oleh Mycobacterium tuberculosis. ${ }^{1}$ Penularan terjadi melalui udara dari droplet infeksi. Tuberkulosis dapat merusak jaringan tubuh mana pun, tetapi paru-paru adalah yang paling umum terinfeksi. Sumber infeksi ialah penderita tuberkulosis paru yang membatukkan 
dahaknya. Penularan umumnya terjadi pada ruangan dengan ventilasi kurang. Sinar matahari dapat membunuh kuman dengan cepat sedangkan pada ruangan gelap kuman dapat hidup. ${ }^{2}$

Bakteri penyebab tuberkulosis berbentuk batang langsing dan tergolong dalam kelompok bakteri tahan asam. Oleh karena itu, $M$. tuberculosis disebut juga sebagai basil tahan asam (BTA). ${ }^{3}$ Diagnosis TB dapat ditegakkan dengan melakukan pemeriksaan mikroskopis BTA pada sputum penderita. Apabila TB dapat dideteksi secara dini dan diobati dengan tuntas maka pengidap dapat cepat menjadi non-infeksius, sembuh, serta tidak terjadi resistensi obat. Pemeriksaan BTA diharapkan dapat membantu mengendalikan infeksi TB di komunitas. ${ }^{4}$

Dalam menegakkan diagnosis TB, standar diagnosisnya ialah kultur kuman TB. Salah satu metode pewarnaan BTA ialah metode Ziehl-Neelsen. Selain metode Ziehl-Neelsen terdapat metode Tan Thiam Hok serta Auramin-Phenol Fluorokrom. Metode Fluorokrom memiliki sensitivitas yang lebih tinggi sedangkan metode ZiehlNeelsen baru memberikan hasil positif bila terdapat $>10^{3}$ organisme/ml sputum. ${ }^{5}$ Kelemahan dari metode Flurokrom ialah memerlukan peralatan yang mahal. Metode pewarnaan Ziehl- Neelsen merupakan metode yang sederhana, memiliki tingkat sensitivitas serta spesitifitas yang cukup tinggi, dan yang paling sering digunakan.

Hingga saat ini TB merupakan masalah kesehatan dunia. ${ }^{2}$ WHO menyatakan 22 negara dengan beban tuberkulosis paru tertinggi di dunia 50\%-nya berasal dari negara-negara Afrika dan Asia serta Amerika (Brasil). Hampir semua negara ASEAN masuk dalam kategori 22 negara tersebut, kecuali Singapura dan Malaysia. Pada tahun 2014, kasus TB yang menyebabkan kematian sebanyak 2 juta penduduk di dunia, dengan perbandingan laki-laki sebanyak 890.000 korban, perempuan sebanyak 480.000 korban, dan anak-anak sebanyak 130.000 korban. $^{6}$

Di negara berkembang kematian karena infeksi bakteri tuberkulosis mencakup 25\% dari keseluruhan kasus di dunia, yang sebenarnya dapat dicegah sehubungan dengan telah ditemukannya kuman penyebab TB. Kematian tersebut disebabkan karena tidak terdeteksinya kasus dan kegagalan pengobatan. Data Program Pemberantasan Tuberkulosis (P2 TB) di Indonesia menunjukkan peningkatan kasus dari tahun ke tahun. Dengan jumlah pasien sekitar $10 \%$ dari total pasien TB didunia. Indonesia merupakan negara ketiga terbanyak di dunia setelah India dan Cina. Diperkirakan setiap tahun ada 539.000 kasus baru dan kematian 101.000 orang. Insidensi kasus TB BTA positif sekitar 110 per 100.000 penduduk.

Berdasarkan data Riset Kesehatan Dasar (Riskesdas) 2014, 5 provinsi dengan revalensi TB tertinggi di Indonesia yaitu, Papua, Papua Barat, Maluku, DKI Jakarta, dan Sulawesi Utara. ${ }^{8}$ Pengidap TB pada laki-laki lebih banyak 1,5 dibandingkan pada perempuan, dan empat kali lebih tinggi pada masyarakat berpendidikan rendah dibandingkan yang berpendidikan tinggi. Rentang usia TB pada kasus kontak 28-46 tahun pada laki-laki dan 20-56 tahun pada perempuan. Data tahun 2014, kota Manado memberikan kontribusi pasien TB terbanyak di provinsi Sulawesi Utara. Di mana dari 15 orang penderita, 14 orang $(93,33 \%)$ berusia produktif (19-55 tahun) dan hanya 1 orang $(6,67 \%)$ berusia 56 tahun. $^{9}$

Dari uraian di atas, diketahui bahwa masih banyak terdapat kasus TB di Indonesia. Dan berdasarkan hasil observasi awal di Puskesmas Bailang pasien suspek TB pada tahun 2015 terdapat sebanyak 262 pasien, sedangkan pasien suspek TB di Puskesmas Bengkol sebanyak 288 pasien. Oleh sebab itu, penulis tertarik melakukan penelitian identifikasi Mycobacterium tuberculosis pada sputum penderita batuk $\geq 2$ minggu dengan pewarnaan ZiehlNeelsen di Puskesmas Bailang dan Bengkol agar supaya TB dapat dideteksi dan diterapi secara cepat dan tepat dan diharapkan dapat menurunkan kasus TB di Indonesia terutama di Kota Manado. 


\section{METODE PENELITIAN}

Jenis penelitian ini ialah deskriptif yang bertujuan untuk mengetahui hasil diagnostik Mycobacterium tuberculosis dari sputum penderita batuk $\geq 2$ minggu dengan pewarnaan basil tahan asam metode Ziehl-Neelsen di Puskesmas Bailang dan Puskesmas Bengkol Manado. Penelitian ini dilaksanakan pada bulan Agustus 2016 sampai dengan November 2016. Pengambilan sampel dilakukan di dua Puskesmas berbeda di Manado yaitu Puskesmas Bailang dan Puskesmas Bengkol. Pemeriksaan sampel dilakukan di Laboratorium Mikrobiologi Fakultas Kedokteran Universitas Sam Ratulangi Manado.

Populasi penelitian ialah pasien dengan keluhan batuk $\geq 2$ minggu yang datang berobat ke Puskesmas pada bulan Agustus 2016 sampai November 2016. Sampel penelitian ialah sputum penderita batuk $\geq 2$ minggu di Puskesmas Bailang dan Puskesmas Bengkol. Pengambilan sampel menggunakan cara total sampling pada kurun waktu Agustus 2016 sampai November 2016.

\section{HASIL PENELITIAN}

Berdasarkan penelitian yang dilakukan ditemukan 25 pasien batuk $\geq 2$ minggu terdiri dari 12 pasien di Puskesmas Bailang dan 13 pasien di Puskesmas Bengkol.

Tabel 1. Distribusi pasien berdasarkan jenis kelamin

\begin{tabular}{lcc}
\hline Jenis kelamin & Jumlah & \% \\
\hline Laki-laki & 18 & 72 \\
Perempuan & 7 & 28 \\
Total & 25 & 100 \\
\hline
\end{tabular}

Penderita batuk $\geq 2$ minggu terbanyak ditemukan pada laki-laki yaitu 18 pasien (72\%) dibandingkan dengan perempuan yaitu 7 pasien (28\%). Tabel 2 memperlihatkan bahwa penderita batuk $\geq 2$ minggu terbanyak ditemukan pada usia 36-55 tahun yaitu 12 pasien (48\%) sedangkan paling sedikit ditemukan pada usia 56-79 tahun yaitu 3 pasien (12\%)
Tabel 2. Distribusi pasien berdasarkan usia

\begin{tabular}{ccc}
\hline Usia (tahun) & Jumlah & \% \\
\hline $0-14$ & 0 & 0 \\
$15-34$ & 10 & 40 \\
$35-54$ & 12 & 48 \\
$\geq 55-65$ & 3 & 12 \\
Total & 25 & 100 \\
\hline
\end{tabular}

Tabel 3 memperlihatkan distribusi hasil pemeriksaan BTA di kedua puskesmas. Di Puskesmas Bailang ditemukan 1 pasien $(8,33 \%)$ positif dan 11 pasien $(91,67 \%)$ negatif sedangkan di Puskesmas Bengkol tidak ditemukan pasien BTA positif.

Tabel 3. Distribusi hasil pemeriksaan BTA

\begin{tabular}{lcc}
\hline Hasil & Jumlah & \% \\
\hline BTA (+) & 1 & 4 \\
BTA (-) & 24 & 96 \\
Total & 25 & 100 \\
\hline
\end{tabular}

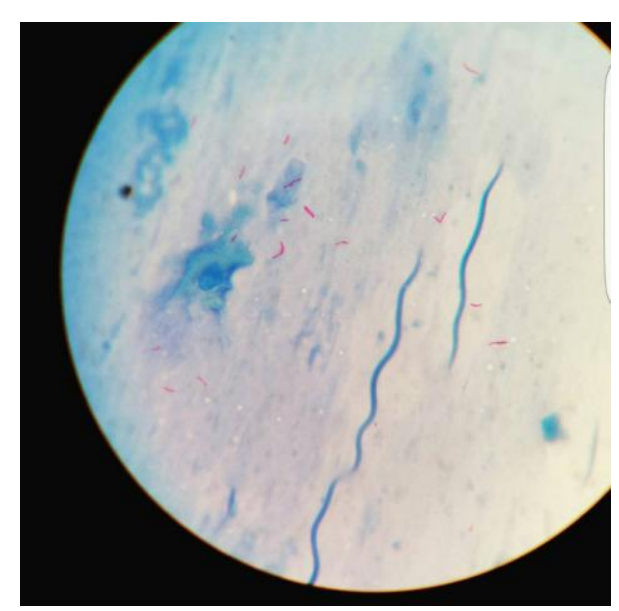

Gambar 1. Pemeriksaan sputum dengan pewarnaan Ziehl Neelsen memperlihatkan BTA positif berbentuk batang

\section{BAHASAN}

Penelitian ini bertujuan untuk mengetahui hasil diagnostik Mycobacterium tuberculosis dari sputum penderita batuk $\geq 2$ minggu di Puskesmas Bailang dan Bengkol. Sesuai kriteria inklusi ditemukan total 25 pasien yang datang ke puskesmas dengan keluhan batuk $\geq 2$ minggu pada bulan Agustus hingga November 2016.

Dari hasil penelitian yang diperoleh, gejala batuk $\geq 2$ minggu lebih tinggi angka 
kejadiannya pada laki-laki dibandingkan perempuan. Hal ini sesuai dengan penelitian di India dan Romania yang menunjukkan bahwa risiko laki-laki untuk terinfeksi TB paru sebesar 2,5 kali dibandingkan dengan perempuan. ${ }^{10,11} \mathrm{Di}$ Indonesia laki-laki mempunyai risiko menderita TB 1,6 kali dibandingkan dengan perempuan. Data dari Depkes RI tahun 2015 menunjukkan bahwa kelompok laki-laki $10 \%$ lebih banyak ditemukan kasus TB dibandingkan perempuan. ${ }^{12}$ Penelitian yang dilakukan oleh Korua et al. ${ }^{12}$ di RSUD Noongan pada tahun 2015 juga memberikan hasil bahwa kasus BTA positif lebih banyak pada laki-laki $(74,41 \%)$ dibandingkan perempuan $(25,59 \%) .{ }^{11}$ Dari penelitian di Bailang dan Bengkol, didapatkan data pada tahun 2015 di Puskesmas Bailang yang menunjukkan adanya lebih banyak pasien laki-laki suspek TB (153 pasien) dibandingkan dengan perempuan (109 pasien), sedangkan data dari Puskesmas Bengkol juga menunjukkan hal serupa, bahwa lebih banyak pasien lakilaki suspek TB (169 pasien) dibandingkan perempuan (119 pasien).

Kejadian TB paru lebih tinggi pada laki-laki dibandingkan pada perempun; hal ini mungkin disebabkan karena kebiasaan laki-laki yang sering merokok dapat menurunkan sistem pertahanan tubuh. Asap panas yang berhembus terus menerus masuk kedalam rongga mulut merupakan rangsangan panas yang menyebabkan perubahan aliran darah dan mengurangi pengeluaran ludah. Akibatnya rongga mulut menjadi kering sehingga dapat mengakibatkan perokok berisiko lebih besar terinfeksi bakteri sehingga wajar bila perokok sering disebut sebagai agen dari penyakit TB paru. ${ }^{10,11}$

Pada penelitian ini penderita batuk $\geq 2$ minggu lebih sering terjadi pada usia 36-55 tahun yaitu sebanyak 12 pasien (48\%) dari 25 kasus suspek TB yang ditemukan Tabel 2). Gambaran penderita TB paru dalam penelitian ini sesuai dengan penelitian yang dilakukan di NTB tahun 2013. Pada penelitian tersebut ditemukan bahwa usia pertama kali didiagnosis TB paru paling banyak terdapat pada kelompok usia produktif antara umur 11-55 tahun $(71,1 \%)$. Kelompok usia tersebut merupakan usia produktif dalam rangka pemenuhan kebutuhan hidupnya. Lingkungan kerja yang padat serta berhubungan dengan banyak orang juga dapat meningkatkan risiko terjadinya TB paru. Apabila seseorang sakit akibat TB paru, hal tersebut akan berakibat pada kehilangan pendapatan tahunan rumah tangganya sekitar 20\%$30 \%$. Jika pengidap TB paru meninggal akibat TB paru, maka akan kehilangan pendapatannya sekitar 15 tahun. ${ }^{7,12}$

Distribusi hasil pemeriksaan BTA pada pasien batuk $\geq 2$ minggu di Puskesmas Bailang dengan hasil positif ditemukan sebanyak 1 kasus (8,33\%). Jika dibandingkan dengan tahun 2015 kasus BTA positif di Puskesmas Bailang ditemukan sebanyak 27 pasien $(9,67 \%)$ dari 262 pasien suspek TB. Dapat dilihat bahwa persentase pasien dengan BTA positif di Puskesmas Bailang terjadi penurunan, tetapi karena profil puskesmas ini dibuat dalam kurun waktu satu tahun sedangkan penelitian yang peneliti lakukan hanya dalam kurun waktu empat bulan maka persentase ini tidak dapat dijadikan acuan bahwa terjadinya penurunan pasien dengan BTA positif di puskesmas Bailang.

Berbeda dengan Puskesmas Bengkol yang tidak ditemukan hasil BTA positif pada penderita batuk $\geq 2$ minggu. Berdasarkan profil puskesmas pada tahun 2015 kasus BTA positif sebanyak 23 pasien dari 288 pasien suspek TB (7,99\%). Hal ini dapat disebabkan karena waktu penelitian yang singkat sehingga tidak ditemukan BTA positif di puskesmas ini. Dari hasil penelitian yang ditemukan peneliti ini dapat juga menunjukkan telah berhasilnya program pemerintah dalam melaksanakan pengobatan TB paru.

\section{SIMPULAN}

Hasil pemeriksaan BTA di Puskesmas Bailang ditemukan 1 pasien $(8,33 \%)$ positif dan 11 pasien $(91,67 \%)$ negatif, sedangkan di Puskesmas Bengkol tidak ditemukan pasien dengan BTA positif. 


\section{DAFTAR PUSTAKA}

1. Utji R, dan Harun H. Kuman tahan asam. Buku Ajar Mikrobiologi Kedokteran (Edisi Revisi). Jakarta: Binarupa Aksara; p. 227-36.

2. Departemen Kesehatan RI. Pointers Menkes Menyambut Hari TBC Sedunia 2007. Available from: www.depkes.go.id

3. Werdhani RA. Patofisiologi, Diagnosis, dan Klasifikasi Tuberkulosis. Departemen Ilmu Kedokteran Komunitas, Okupasi, dan Keluarga FKUI.

4. Perhimpunan Dokter Paru Indonesia. Konsensus tuberkulosis: Pedoman Diagnosis dan Penatalaksanaan DI Indonesia. Jakarta, 2006. Available from:

klikpdpi.com/konsensus/Xsip/tb.pdf.

5. Muzaffar R, Batool S, Azis A, Naqvi A,

Rizvi A. Evaluation of the FASTPLAQUETB Assay for Direct Detection of Mycobacterium tuberculosis in Sputum Specimens. Int J Tuberc Lung Dis. 2002; 6(7):635-40.

6. World Health Organization. Global Tuberculosis Report $201520^{\text {th }}$ edition. Available from: www.who.int 2015

7. Kementerian Kesehatan RI Direktorat Jendral Pengendalian Penyakit dan Penyehatan Lingkungan. Pedoman Nasional Pengendalian Tuberkulosis. Jakarta: Kementerian Kesehatan RI, 2014.

8. Badan Penelitian dan Pengembangan Kesehatan Depkes RI. Riset Kesehatan Dasar 2014. Jakarta: Balitbangkes
Depkes RI, 2014.

9. Departemen Kesehatan RI. Buku Saku Profil Kesehatan Sulawesi Utara. Available from: www.depkes.go.id 2014.

10. Kolappan C, Gopi PG, Subramani R, Narayanan PR. Selected biological and behavioural risk factors associated with pulmonary tuberculosis. Int $\mathbf{J}$ Tuberculosis Lung Dis. 2007;11(9): 999-1003.

11. Ndishimye $P$, Domokos $B$, Stillo $J$, Seghrouchni F, Mrabet $O$, Homorodean D, et al. A case control study of risk factors associated with pulmonary tuberculosis in Romania: Experience at a clinical hospital of pulmonology. Clujul Medical. 2016. Available from: http://www.clujulmedical.umfcluj.ro/in dex.php/cjmed/article/view/652.

12. Depkes RI. Profil Kesehatan Indonesia 2015. Jakarta: Kementerian Kesehatan RI, 2016.

13. Korua ES, Kapantow NH, Kawatu PAT. Hubungan antara umur, jenis kelamin, dan kepadatan hunian dengan kejadian TB paru pada pasien rawat jalan di Rumah Sakit Umum Daerah Noongan [Skripsi]. Manado: Universitas Sam Ratulangi; 2015.

14. Hapsari AR, Faridah F, Balwa AF, Saraswati LD. Analisis kaitan riwayat merokok terhadap pasien tuberkulosis paru (TB paru) di Puskesmas Srondol. Jurnal Ilmiah Mahasiswa. 2013;3(2). 